\title{
Article
}

\section{CYP1A2 genotype and acute ergogenic effects of caffeine intake on exercise performance: a systematic review}

Grgic, Jozo, Pickering, Craig, Del Coso, Juan, Schoenfeld, Brad J and Mikulic, Pavle

Available at http://clok.uclan.ac.uk/35554/

Grgic, Jozo, Pickering, Craig, Del Coso, Juan, Schoenfeld, Brad J and Mikulic, Pavle (2020) CYP1A2 genotype and acute ergogenic effects of caffeine intake on exercise performance: a systematic review. European Journal of Nutrition . ISSN 1436-6207

It is advisable to refer to the publisher's version if you intend to cite from the work. http://dx.doi.org/10.1007/s00394-020-02427-6

For more information about UCLan's research in this area go to http://www.uclan.ac.uk/researchgroups/ and search for <name of research Group>.

For information about Research generally at UCLan please go to http://www.uclan.ac.uk/research/

All outputs in CLoK are protected by Intellectual Property Rights law, including Copyright law. Copyright, IPR and Moral Rights for the works on this site are retained by the individual authors and/or other copyright owners. Terms and conditions for use of this material are defined in the policies page.

\section{CLoK}

Central Lancashire online Knowledge www.clok.uclan.ac.uk

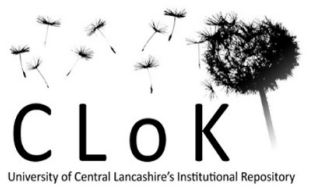


1 CYP1A2 genotype and acute ergogenic effects of caffeine intake on exercise

2 performance: a systematic review

3 Jozo Grgic, ${ }^{1}$ Craig Pickering, ${ }^{2}$ Juan Del Coso,${ }^{3}$ Brad J. Schoenfeld, ${ }^{4}$ Pavle Mikulic, ${ }^{5}$

$4{ }^{1}$ Institute for Health and Sport (IHES), Victoria University, Melbourne, VIC, Australia

$5 \quad{ }^{2}$ Institute of Coaching and Performance, School of Sport and Wellbeing, University of Central

$6 \quad$ Lancashire, Preston PR1, UK

$7 \quad{ }^{3}$ Centre for Sport Studies, Rey Juan Carlos University, Fuenlabrada, Spain

$8 \quad{ }^{4}$ Department of Health Sciences, Lehman College, Bronx, New York, USA

$9 \quad{ }^{5}$ Faculty of Kinesiology, University of Zagreb, Zagreb, Croatia

10 Running head: $C Y P 1 A 2$ genotype, caffeine, and exercise performance

11 Number of figures: 1

12 Number of tables: 3

13 Abstract word count: 246

14 Manuscript word count: 4334

\section{Corresponding author:}

Jozo Grgic

Institute for Health and Sport (IHES), Victoria University, Melbourne, VIC, Australia 
20 CYP1A2 genotype and acute ergogenic effects of caffeine intake on exercise

21 performance: a systematic review 


\section{Abstract}

Purpose: To systematically review studies that examined the influence of the CYP1A2 $-163 \mathrm{C}>\mathrm{A}$ polymorphism on the ergogenic effects of caffeine and to discuss some of the reasons for the discrepancies in findings between the studies.

Methods: This review was performed in accordance with the PRISMA guidelines. The search for studies was performed through nine databases.

Results: Seventeen studies were included in the review. Based on the included studies, it seems that individuals with the AA or AC/CC genotype may experience an increase in performance following caffeine ingestion. Significant differences between genotypes were found in four studies, and all four reported a more favorable response in the AA vs. AC/CC genotype. These results suggest that if there is an actual genotype-related effect of acute caffeine supplementation, it might be in that direction. In the studies that reported such data for aerobic endurance, the findings are specific to male participants performing cycling time trials (distances of $\geq 10 \mathrm{~km}$ ) and ingesting caffeine 60 minutes before exercise. For highintensity exercise, two studies reported that genotype variations determined the response to caffeine ingestion, even though the differences were either small ( $\sim$ additional repetition in high-load resistance exercise set performed to muscular failure) or inconsistent (i.e., observed only in one out of eight performance tests).

Conclusions: $C Y P 1 A 2$ genotype variations may modulate caffeine's ergogenic effects, but the differences between genotypes were small, inconsistent, or limited to specific exercise scenarios. Future studies with larger sample sizes are needed to fully elucidate this research area.

Keywords: supplements; ergogenic aid; genetics; responses 


\section{Introduction}

Caffeine is one of the most consumed psychoactive drugs in the world [1]. Besides the general population, caffeine is also widely used by athletes because of its ergogenic effects on exercise performance [2]. Based on the available evidence, caffeine ingestion may be ergogenic for different components of exercise performance, such as aerobic and muscular endurance, muscle strength, power, and speed [3]. Such effects are well-established and wellreplicated in the scientific literature [3]. However, the response to caffeine ingestion does not seem to be uniform across individuals, with some experiencing increases in performance following acute caffeine ingestion, while others show no performance-related changes or even decrease following caffeine consumption [4].

The gene CYP1A2 encodes cytochrome P450 1A2, an enzyme responsible for $~ 95 \%$ of caffeine metabolism [5]. An A to C substitution at position 163 (-163C>A; rs762551) in the CYP1A2 gene impacts the speed of caffeine metabolism [6]. Individuals who possess the AA genotype are considered "fast metabolizers" of caffeine, given that this genotype codes for the highly inducible form of the CYP1A2 enzyme [5-8]. Individuals with AC or CC genotype (i.e., C allele carriers) tend to have slower caffeine metabolism and are considered as "slow metabolizers" of caffeine [5-8].

Several studies explored the effects of caffeine supplementation on exercise performance while considering $C Y P 1 A 2-163 \mathrm{C}>\mathrm{A}$ polymorphism [9-13]. The results of these studies, however, are equivocal. Some studies found genotype differences in caffeine's ergogenic effects, as individuals possessing the AA genotype experienced improvements in performance following caffeine ingestion, while those with the $\mathrm{AC}$ or $\mathrm{CC}$ genotype were not positively 
impacted by caffeine ingestion [12]. In contrast to these findings, others have suggested that individuals with the AC genotype experience greater improvements in performance following caffeine ingestion than those who possess the AA genotype [13]. Finally, some studies did not show significant differences in responses to caffeine supplementation between genotypes [9$11]$.

Given the equivocal evidence presented in the literature, we aimed to: (a) systematically review the available studies that have examined the influence of the $C Y P 1 A 2-163 \mathrm{C}>\mathrm{A}$ polymorphism on the ergogenic effects of caffeine; and, (b) discuss some of the reasons for the discrepancies between the studies. A systematic review of the evidence might be of high practical importance as it may help to identify why some individuals have minimal ergogenic or even ergolytic effects after acute caffeine intake. The presented findings might also be of relevance if we consider that the number of companies that offer direct-to-consumer genetic testing aimed to detect individual responses to caffeine and the subsequent popularity of such testing has experienced a substantial increase in recent years [14].

\section{Methods}

\section{Search strategy}

This review was performed while following the Preferred Reporting Items for Systematic Reviews and Meta-Analyses (PRISMA) guidelines [15]. The protocol was not registered. For the purpose of this review, we performed a comprehensive search of the following databases: CINAHL, ERIC, Open Dissertations, Networked Digital Library of Theses and Dissertations, Open Access Theses and Dissertations, PubMed/MEDLINE, Scopus, SPORTDiscus, and Web of Science. In all of these databases, we used the following syntax: (CYP1A2 OR 
genotype OR genetics OR polymorphism) AND (caffeine) AND (exercise OR training OR ergogenic OR performance). Secondary searches were performed by examining the reference lists of all included studies and by performing forward citation tracking through Google Scholar and Scopus. The search for studies concluded on August $28^{\text {th }}, 2020$ and was performed independently by two authors ( $\mathrm{JG}$ and $\mathrm{CP}$ ) of the review to minimize bias in study selection.

\section{Inclusion criteria and data extraction}

We included studies that satisfied the following criteria: (a) written in English as a peerreviewed paper, a thesis, or a dissertation; (b) explored the influence of any of the CYP1A2 $-163 \mathrm{C}>\mathrm{A}$ genotypes on the ergogenic responses to acute caffeine ingestion; (c) included humans as study participants. We extracted the following data from the included studies: (a) author(s) and publication status (i.e., published or unpublished); (b) sample size, CYP1A2 genotype distribution, and participants' characteristics (sex, age, body mass, habitual caffeine intake, and training status); (c) caffeine supplementation protocol and exercise task(s); and (d) main study findings (i.e., caffeine main effects and caffeine $\times$ genotype interaction, where applicable).

\section{Calculation of effect sizes}

Where available, Cohen's $d$ effect sizes were calculated as the caffeine-placebo mean change divided by the pooled SD, separately for each genotype. Effect sizes were interpreted as: “trivial" $(\leq 0.20)$, “small” (0.21-0.50), "medium" $(0.51-0.80)$, and "large" $(>0.80)$. 
The 11-point PEDro scale was used to assess the methodological quality of the included studies [16]. In line with the recommendations, item 1 on the PEDro scale was not included in the total score as it concerns external validity. Besides external validity, items on the checklist refer to randomization, concealed allocation, blinding, attrition, and data reporting. Each item is scored with a 1 (criterion satisfied) or with a 0 (criterion not satisfied or unclear). The maximal score on the PEDro checklist was 10. We classified studies as "excellent" quality (910 points), “good” quality (6-8 points), “fair" quality (4-5 points), or “poor” methodological quality ( $\leq 3$ points) [17]. Two authors (JG and PM) independently performed the methodological quality assessment; any observed differences in the initial scoring were resolved via discussion.

\section{Results}

\section{Study selection}

In the primary search, there was a total of 1621 potentially relevant references. Of the 1621 screened references, 1593 were excluded based on title or abstract; 28 full-text papers were read, and 14 studies were included in the review. Secondary searches resulted in another 1684 search results, and with the inclusion of three additional studies (Figure 1). Therefore, the final number of included studies was 17 [9-13, 18-29]. Fourteen studies were published in peer-reviewed journals; two were theses [20, 25], and one was a dissertation [21].

\section{Aerobic endurance}


Eleven studies explored the influence of $C Y P 1 A 2-163 \mathrm{C}>\mathrm{A}$ polymorphism on the responses to caffeine ingestion during aerobic exercise (Table 2). Of these studies, eight combined the AC and CC genotype in one group and compared it to the AA genotype groups; two studies compared the effects across all three genotypes (Table 1). Additionally, in one study, only a main effect of caffeine was explored in a sample consisting exclusively of 14 participants with the AC genotype [25]. Sample sizes in individual studies ranged from 11 to 101 participants (pooled number of participants: 396). All studies included either a mixed-sex sample or included only men. A significant main effect of caffeine was observed in all studies, except in the study by Algrain et al. [9], where there were no significant differences between caffeine and placebo. A significant caffeine $\times$ genotype interaction was found in two studies $[12,26]$. In one, a greater ergogenic effect was found in the AA genotype as compared to AC/CC genotype [26]. In another, an ergogenic effect was found in the AA genotype with both used caffeine doses ( 2 and $4 \mathrm{mg} / \mathrm{kg}$ ); no increases in performance in the AC genotype occurred with any of the used caffeine doses, and decreases in performance in the $\mathrm{CC}$ genotype with the consumption of $4 \mathrm{mg} / \mathrm{kg}$ of caffeine, but not $2 \mathrm{mg} / \mathrm{kg}$ of caffeine [12]. Across the individual studies, effect sizes of caffeine on performance for the AA genotype ranged from 0.16 to 0.67 (Table 2). For the AC/CC genotype, effect sizes ranged from 0.07 to 0.36. In the two studies that presented data for the CC genotype, the effect size amounted to 1.35 (favoring of placebo) in one study [12], and 0.12 (favoring of caffeine) in another [29].

\section{High-intensity exercise}

Eight studies explored the influence of $C Y P 1 A 2-163 \mathrm{C}>\mathrm{A}$ polymorphism on the responses to caffeine ingestion during high-intensity exercise (Table 2). The performance tests in these studies included muscle endurance tasks in resistance exercise, isometric handgrip strength tests, jumping (countermovement jump, spike jump, and squat jump), sprinting (Wingate test, 
sprint velocity test), agility tests, and sport-specific (tennis and handball) skill tests. Of these studies, six conducted a comparison of effects between the AA and AC/CC genotype, one compared the effects across all three genotypes, and in one study [25], only a main effect of caffeine was explored in a sample of participants with the AC genotype (Table 1). Across the studies, sample sizes ranged from 14 to 100 participants (pooled number of participants: 253). Four studies included a mixed-sex sample, and four included only men (Table 1). Significant main effects of caffeine were observed in all studies, but not necessarily across all exercise tasks, as some studies $[22,28,29]$ did not find significant differences between caffeine and placebo for agility tests, isometric handgrip strength, or ball velocity throw tests. A significant caffeine $\times$ genotype interaction was found in two studies $[23,28]$. In one study, resistance exercise performance was enhanced following caffeine ingestion in the AA genotype, while no ergogenic effects were observed in the AC/CC genotype [23]. In another study, a significant caffeine $\times$ genotype interaction was found in one out of eight performance tests (ball throw from 7-m), with ergogenic effects observed for the AA, but not AC/CC genotype [28]. Effect sizes of caffeine on performance for the AA genotype ranged from 0.0 to 1.87 (Table 2). For the AC/CC genotype, effect sizes ranged from -0.23 to 1.27 . In the only study that presented data separately for the CC genotype, the effect sizes ranged from -0.37 to 0.36 .

\section{Methodological quality}

The average score on the PEDro checklist was 8.6 points (range: 7 to 9 points). Thirteen studies were classified as "excellent" methodological quality, and four as "good" methodological quality. Individual scores are presented in Table 3.

\section{Discussion}


Based on the results presented in the current literature, it generally seems that individuals with the $C Y P 1 A 2 \mathrm{AA}$ or AC/CC genotype may experience an increase in performance following caffeine ingestion. Four included studies found significant differences between AA and AC or CC genotype, and in all of these studies, the effects of caffeine favored the AA genotype. These results suggest that if there is a true genotype effect in the population, it might be in that direction. Still, several important factors that might be responsible for the discrepancies in findings and the practical relevance of the results need to be considered when interpreting these findings.

\section{Aerobic endurance}

Of the studies that examined the effects of caffeine on measures of aerobic endurance, only two reported significant caffeine $\times$ genotype interaction, whereby individuals with the AA genotype experienced greater improvements in exercise performance than the participants with the AC/CC genotype $[12,26]$. These studies used either $10-\mathrm{km}$ or $40-\mathrm{km}$ cycling time trials. Some studies that reported no significant caffeine $\times$ genotype interaction used shorter duration time trials (e.g., 3-km in two studies; [11, 13]). In the study by Pataky et al. [13], the increases in performance even favored the AC genotype, even though the difference was not statistically significant $(p=0.12)$. Therefore, significant between-genotype differences in response to caffeine supplementation may be only present in longer duration aerobic events. This hypothesis seems plausible, given that the effects of caffeine may increase with the increase in the duration of the aerobic task [30]. However, one study explored the effects of caffeine using Olympic-distance triathlons as the exercise task and did not find caffeine $x$ genotype interaction (even though a main effect of caffeine was observed), suggesting that the duration of the task might not be of such large importance [21]. 
In the two studies that reported significant differences between the genotypes, the samples consisted exclusively of men $[12,26]$. All studies that included a mixed-sex sample did not report significant differences in response to caffeine ingestion between genotypes (Table 2). As men and women seem to experience a similar response to caffeine ingestion during aerobic exercise, it does not seem that the inclusion of a mixed-sex sample should be considered as a limitation of these studies [31, 32]. Albeit speculative, it is conceivable that genotype differences impact the individual variation in response to caffeine ingestion in men, but not in women. In support of this hypothesis, there is evidence that CYP1A2 activity is lower in women than men, which might explain these inconsistent findings [33]. Instead of excluding females, future research should consider including both males and females and plot the data separately to see if there indeed is a difference between sexes.

One potentially confounding issue is that studies generally did not report if the participants were current smokers. This might be important given that smoking may affect CYP1A2 activity. A recent meta-analysis reported that only smokers demonstrated differences in CYP1A2 activity between the AA vs. CC and AC vs. CC genotype [34]. In a subgroup of studies that included non-smokers, no differences were found in CYP1A2 activity between genotypes. In non-smokers, only in heavy coffee consumers (more than 3 cups per day), the AA genotype had higher CYP1A2 activity than in C allele carriers [35]. In the two studies that specifically noted that the participants were non-smokers, the authors did not find significant caffeine $\times$ genotype interaction $[9,20]$. Future studies on the topic should specify the information on the smoking status of the participants to allow for a more informed comparison of results between the studies. Other factors, such as vegetable intake [36], phase of the menstrual cycle [37], and oral contraceptive use [38], may also affect caffeine metabolism, and they should be considered in future studies. While potentially relevant, some 
of these factors may not impact caffeine's ergogenic effects, as recent studies observed similar improvements in exercise performance following caffeine ingestion in the early follicular, pre-ovulatory, and mid-luteal phases of the menstrual cycle $[39,40]$.

Future research is needed to explore the influence of caffeine ingestion timing, as some have hypothesized that different effects may be observed when using longer waiting times from caffeine ingestion to the start of the exercise session [41]. Specifically, given that $\mathrm{C}$ allele carriers are considered slow caffeine metabolizers, they might need to ingest caffeine 90 or 120 minutes before exercise to experience ergogenic effects [41]. There might be some credence to this hypothesis if we consider the finding by McGrath [20]. In this study, the main performance task consisted of a 30-minute cycling time trial performed 175 minutes following caffeine ingestion. The participants ingested caffeine 60 -minutes before performing 115-minutes of steady-state cycling. Only after steady-state cycling, the participants performed the main performance trial. A main effect of caffeine was observed, but no caffeine $\times$ genotype interaction, suggesting that similar responses to caffeine supplementation between genotypes occurred, possibly because of the timing of caffeine supplementation. A limitation of the study is that the participants first performed steady-state cycling. This aspect of the study design is important to mention given that exercise may impact CYP1A2 activity [42]. Furthermore, the study by McGrath [20] had a small sample of 11 participants, and this limitation should be considered when interpreting these findings.

Overall, there is some evidence that $C Y P 1 A 2-163 \mathrm{C}>\mathrm{A}$ polymorphism may impact the ergogenic effects of caffeine on aerobic endurance. While individuals that possess the AC/CC genotype still may experience improvements in performance, there is some evidence indicating that AA homozygotes obtain a higher ergogenic effect from acute caffeine intake 
than $\mathrm{C}$ allele carriers. However, to date, such findings are observed only in: (a) male participants; (b) cycling time trials that included $\mathrm{a} \geq 10 \mathrm{~km}$ distance; and (c) protocols that included caffeine ingestion 60 minutes before exercise.

\section{High-intensity exercise}

Of the eight studies that used high-intensity exercise tasks, two reported a significant caffeine $\times$ genotype interaction $[23,28]$. In one study [28] conducted among 31 professional handball players, significant genotype differences were observed in ball throw velocity from 7-m. This study found improvements in individuals with the AA genotype following caffeine ingestion, whereas participants with the $\mathrm{AC} / \mathrm{CC}$ genotype did not benefit from caffeine ingestion on this specific test. However, these results were inconclusive given that no significant genotype differences were observed for other similar outcomes, such as ball throw velocity from 9-m, and ball throw velocity from 7 and 9-m with a goalkeeper. In another study, individuals who possessed the AA genotype experienced improvements in resistance exercise performance following the ingestion of $6 \mathrm{mg} / \mathrm{kg}$ of caffeine [23]. Exercise performance did not improve following caffeine ingestion in those with the AC/CC genotype. It should be noted, however, that the difference in exercise performance was small. Specifically, following caffeine ingestion, the AA genotype group completed an average of one repetition more (range: 0.3 to 1.1 repetitions) in a set with $85 \%$ of one-repetition maximum (1RM) performed to momentary muscular failure. In the $\mathrm{AC} / \mathrm{CC}$ group, the number of performed repetitions was the same following placebo and caffeine ingestion. A subsequent study performed by Grgic et al. [18] did not find a caffeine $\times$ genotype interaction using the same exercise task as Rahimi [23], only a lower dose of caffeine (i.e., $3 \mathrm{mg} / \mathrm{kg}$ ). 
Besides assessing the number of repetitions, Grgic et al. [18] also assessed the velocity and power output of each repetition. For the analysis, these authors also matched the number of performed repetitions between caffeine and placebo conditions and observed that caffeine ingestion substantially affected the "quality" of performed repetitions in both genotypes. In the Rahimi [23] study, the only assessed outcome was the quantity of performed repetitions, but not its overall quality. From a practical perspective, the quality of repetitions may be of greater relevance. As shown by studies that used velocity-based training, training at a lower velocity loss often produces similar or superior training adaptations as training at a higher velocity loss, despite the higher number of repetitions performed when training at a higher velocity loss $[43,44]$. Future studies should assess both the quantity and quality of performed repetition to reconcile these equivocal findings.

Besides resistance exercise, studies also utilized other high-intensity tasks, such as jumping and Wingate test performance $[18,22,24]$. None of these studies found a significant caffeine $\times$ genotype interaction in the analyzed outcomes, even though most reported a significant main effect of caffeine. In line with these observations, the study by Southward [25] - that included only 14 participants with the AC genotype-also reported improvements in resistance exercise and jumping performance following caffeine ingestion. The effect size in this study was similar to the effects of caffeine previously reported among samples with the AA genotype and among those that were not genotype-specific [18, 22, 45, 46].

A limitation of the majority of studies conducted on the topic is pooling the AC and CC genotype into a single group, which is relevant as the response may not be uniform across these two genotypes [12]. Out of the studies that utilized high-intensity exercise tasks, only 
one large sample size $(n=100)$ study examined the effects across all three genotypes [29]. This study did not find significant genotype differences, even though caffeine ingestion enhanced muscular endurance (but not isometric strength, agility, and jump height). Still, this study is also unique by the inclusion of adolescents as study participants, given that all other studies included young adults. Overall, based on the current body of evidence, CYP1A2 genotype variations might impact the ergogenic effect of caffeine supplementation on highintensity exercise performance. However, the differences between genotypes were either small or inconsistent, highlighting the need for future research.

\section{Methodological considerations}

Some of the discrepancies in findings between studies might also be related to the source and dose of caffeine. Guest et al. [12] demonstrated ergolytic effects of caffeine in the CC genotype with the consumption of $4 \mathrm{mg} / \mathrm{kg}$ of caffeine, but not $2 \mathrm{mg} / \mathrm{kg}$ of caffeine. Two additional studies $[23,26]$ that observed genotype differences also used a higher dose of caffeine (i.e., $6 \mathrm{mg} / \mathrm{kg}$ ). These results suggest that the dose might influence CYP1A2 genotype responses to acute caffeine ingestion. Still, it should be noted that other studies $[13,29]$ also used higher doses of caffeine and did not find genotype differences, suggesting that dose alone is not likely the sole explanation for the differences in findings.

There is growing evidence that consuming alternate sources of caffeine such as chewing gums and caffeine gels may enhance exercise performance [47]. One included study [9] used chewing gums and did not observe general ergogenic effects of caffeine. The lack of an ergogenic might be because an absolute dose of $255 \mathrm{mg}$ was used, which might have created differences in responses due to variation in body mass among participants. In contrast, caffeine's ergogenic effect is most commonly observed when providing relative doses ranging 
from 3 to $6 \mathrm{mg} / \mathrm{kg}$ [48]. To avoid confounding factors such as the absence of an ergogenic effect (due to administration of absolute caffeine doses), future studies that aim to explore the influence of genotype on the response to caffeine ingestion should strive to employ optimal protocols of caffeine supplementation that include providing dose relative to body mass.

Factors such as participants' training status and their habitual caffeine intake should also be considered when interpreting the evidence [49-51]. In all four studies [12, 23, 26, 28] that reported significant between-genotype differences, the participants were either athletes or resistance-trained individuals. This might suggest that caffeine's effects, according to the CYP1A2 genotype, might be related to training status. However, other studies $[18,29]$ also included trained individuals but did not observe genotype differences, highlighting the equivocal nature of the evidence. Future studies on the topic may consider including trained and untrained individuals to establish a relationship between caffeine's ergogenic effects, training status, and CYP1A2 genotype. Most studies included participants that were "low" habitual caffeine intake users (Table 2). Therefore, from this standpoint, the included studies were reasonably uniform. Still, some studies $[26,27]$ included "low", "moderate", and "high" habitual users as study participants, which might be a limitation as there is evidence indicating that habitual caffeine intake may influence the ergogenic effects of acute caffeine ingestion $[50,51]$. Therefore, when conducting studies on this topic, it would be important to include a sample with different CYP1A2 genotypes but with homogeneous habitual caffeine intake.

Another important methodological aspect of the included studies is their sample size. Studies that found significant genotype differences included sample sizes ranging from 30 to 101 participants. In contrast, most studies that did not find significant genotype differences involved smaller sample sizes, with one study conducted among a cohort of 11 participants 
360 [20]. Because of the small sample size, some of the included studies might have been

361 statistically underpowered to detect significant differences. While this might be the case, it 362 should also be considered that the study by Spineli et al. [29] included 100 participants and 363 did not find significant genotype differences, suggesting that the differences in sample sizes 364 alone cannot be the explanation for the divergent findings.

\section{Methodological quality of the included studies}

We included studies published in peer-reviewed journals as well as theses and dissertations in this systematic review. This may be considered as a limitation given that studies published in journals might be of higher methodological quality, as the peer-review process is considered to present a form of quality control. Based on the PEDro checklist, however, all included studies were of good or excellent methodological quality, regardless of their publication status. Therefore, we believe that the inclusion of unpublished documents could be considered as a strength of the review due to "publication bias," which dictates that studies reporting larger and statistically significant effect sizes tend to be more often published than studies reporting non-statistically significant data [52]. Therefore, basing the conclusions of a review only on the published literature may introduce a source of bias. Indeed, of the three unpublished documents included in the review, two did not report significant caffeine $x$ genotype interaction, while one study was limited by the inclusion of only AC genotype in the review (i.e., no between-genotype comparison could be performed) [20, 21, 25].

\section{Practical application}

Based on the current body of research, it is questionable if the knowledge of the CYP1A2 genotype represents a worthwhile means of informing caffeine-use strategies in sport. An 
individual's response to caffeine, and optimal caffeine-use strategy to increase performance, is likely complex, with aspects such as habitual caffeine use, method of caffeine intake, and situational feelings of stress and anxiety potentially influencing the response to a given dose of caffeine [7]. While there might be a genetic influence on the performance response to caffeine in sport, $C Y P 1 A 2$ represents only one such gene that has been demonstrated to potentially play a role, with others, such as $A D O R A 2 A$ tentatively identified $[27,28,53,54]$. Future research, on a wider panel of genetic variants, should help to provide greater clarity here. For now, we suggest that athletes, coaches and support staff should take an evidenceguided, experiential approach to caffeine, using current research-based guidelines as a starting point, and then utilizing self-experimentation to settle on a caffeine dose optimized for their unique make-up and circumstances. Finally, while the popularity of genetic testing in sport has increased in recent years [14], for those interested in caffeine supplementation, it currently seems that individual CYP1A2 genotype identification might not provide a definitive answer to the individual response to acute caffeine intake.

\section{Conclusion}

Based on the results of the studies included in the review, it seems that individuals with the CYP1A2 AA or AC/CC genotype may experience an increase in performance following caffeine ingestion. Even though significant differences between genotypes were found only in four studies, all four reported a more favorable response in the AA genotype. These results suggest that if there is an actual genotype-related effect of acute caffeine supplementation in the population, it is likely in that direction. In the studies that reported such data for aerobic endurance, the findings are specific to male participants performing cycling time trials (distances of $\geq 10 \mathrm{~km}$ ) and ingesting caffeine 60 minutes before exercise. For high-intensity exercise, two studies reported that genotype variations determined the response to caffeine 
409 ingestion, even though the differences were either small ( $\sim$ additional repetition in high-load 410 resistance exercise set performed to failure) or inconsistent (i.e., observed only in one out of 411 eight performance tests). In summary, CYP1A2 genotype variations may modulate caffeine's

412 ergogenic effects, but the differences between genotypes were small, inconsistent, or limited 413 to specific exercise scenarios. 


\section{References}

1. Mitchell DC, Knight CA, Hockenberry J et al (2014) Beverage caffeine intakes in the U.S. Food Chem Toxicol 63:136-142

2. Del Coso J, Muñoz G, Muñoz-Guerra J (2011) Prevalence of caffeine use in elite athletes following its removal from the World Anti-Doping Agency list of banned substances. Appl Physiol Nutr Metab 36:555-561

3. Grgic J, Grgic I, Pickering C et al (2020) Wake up and smell the coffee: caffeine supplementation and exercise performance - an umbrella review of 21 published meta-analyses. Br J Sports Med 54:681-688

4. Sabol F, Grgic J, Mikulic P (2019) The effects of 3 different doses of caffeine on jumping and throwing performance: a randomized, double-blind, crossover study. Int $\mathbf{J}$ Sports Physiol Perform 14:1170-1177

5. Sachse C, Brockmöller J, Bauer S et al (1999) Functional significance of a C $\rightarrow$ A polymorphism in intron 1 of the cytochrome P450 CYP1A2 gene tested with caffeine. Br J Clin Pharmacol 47:445-449

6. Nehlig A (2018) Interindividual differences in caffeine metabolism and factors driving caffeine consumption. Pharmacol Rev 70:384-411

7. Pickering C, Kiely J (2018) Are the current guidelines on caffeine use in sport optimal for everyone? Inter-individual variation in caffeine ergogenicity, and a move towards personalised sports nutrition. Sports Med 48:7-16

8. Wang L, Hu Z, Deng X et al (2013) Association between common CYP1A2 polymorphisms and theophylline metabolism in non-smoking healthy volunteers. Basic Clin Pharmacol Toxicol 122:257-263 
9. Algrain HA, Thomas RM, Carrillo AE et al (2016) The effects of a polymorphism in the cytochrome P450 CYP1A2 gene on performance enhancement with caffeine in recreational cyclists. J Caffeine Res 6:34-39

10. Davenport AD, Jameson TSO, Kilroe SP et al (2020) A randomised, placebocontrolled, crossover study investigating the optimal timing of a caffeine-containing supplement for exercise performance. Sports Med Open 6:17

11. Giersch GE, Boyett JC, Hargens TA et al (2018) The effect of the CYP1A2-163 C>A polymorphism on caffeine metabolism and subsequent cycling performance. $\mathrm{J}$ Caffeine Adenosine Res 8:65-70

12. Guest N, Corey P, Vescovi J et al (2018) Caffeine, CYP1A2 genotype, and endurance performance in athletes. Med Sci Sports Exerc 50:1570-1578

13. Pataky MW, Womack CJ, Saunders MJ et al (2016) Caffeine and 3-km cycling performance: effects of mouth rinsing, genotype, and time of day. Scand J Med Sci Sports 26:613-619

14. Pickering C, Kiely J, Grgic J et al (2019) Can genetic testing identify talent for sport? Genes 10:E972

15. Liberati A, Altman DG, Tetzlaff J et al (2009) The PRISMA statement for reporting systematic reviews and meta-analyses of studies that evaluate healthcare interventions: explanation and elaboration. BMJ 339:b2700

16. Maher CG, Sherrington C, Herbert RD et al (2003) Reliability of the PEDro scale for rating quality of randomized controlled trials. Phys Ther 83:713-721

17. McCrary JM, Ackermann BJ, Halaki M (2015) A systematic review of the effects of upper body warm-up on performance and injury. Br J Sports Med 49:935-942 
18. Grgic J, Pickering C, Bishop DJ et al (2020) CYP1A2 genotype and acute effects of caffeine on resistance exercise, jumping, and sprinting performance. J Int Soc Sports Nutr 17:21

19. Klein CS, Clawson A, Martin M et al (2012) The effect of caffeine on performance in collegiate tennis players. J Caffeine Res 2:111-116

20. McGrath MC (2015) The significance of CYP1A2 genotype on caffeine metabolism and exercise performance. Thesis. Massey University

21. Potgieter S (2013) The effect of caffeine supplementation on Olympic-distance triathletes and triathlon performance in the Western Cape, South Africa. Dissertation. Stellenbosch University

22. Puente C, Abián-Vicén J, Del Coso J et al (2018) The CYP1A2-163C > A polymorphism does not alter the effects of caffeine on basketball performance. PLoS One 13:e0195943

23. Rahimi R (2019) The effect of CYP1A2 genotype on the ergogenic properties of caffeine during resistance exercise: a randomized, double-blind, placebo-controlled, crossover study. Ir J of Med Sci 188:337-345

24. Salinero JJ, Lara B, Ruiz-Vicente D et al (2017) CYP1A2 genotype variations do not modify the benefits and drawbacks of caffeine during exercise: a pilot study. Nutrients $9: 269$

25. Southward K (2016) Effect of caffeine ingestion on aspects of endurance performance and cognition in CYP1A2 hetrozygous A/C male recreational athletes. Thesis. Massey University

26. Womack CJ, Saunders MJ, Bechtel MK et al (2012) The influence of a CYP1A2 polymorphism on the ergogenic effects of caffeine. J Int Soc Sports Nutr 9:7 
27. Carswell AT, Howland K, Martinez-Gonzalez B et al (2020) The effect of caffeine on cognitive performance is influenced by CYP1A2 but not ADORA2A genotype, yet neither genotype affects exercise performance in healthy adults. Eur J Appl Physiol 120:1495-1508

28. Muñoz A, López-Samanes Á, Aguilar-Navarro M et al (2020) Effects of CYP1A2 and ADORA2A Genotypes on the Ergogenic Response to Caffeine in Professional Handball Players. Genes 11:E933

29. Spineli H, Pinto MP, Dos Santos BP et al (2020) Caffeine improves various aspects of athletic performance in adolescents independent of their $163 \mathrm{C}>\mathrm{A}$ CYP1A2 genotypes. Scand J Med Sci Sports doi: 10.1111/sms.13749

30. Shen JG, Brooks MB, Cincotta J et al (2019) Establishing a relationship between the effect of caffeine and duration of endurance athletic time trial events: a systematic review and meta-analysis. J Sci Med Sport 22:232-238

31. Chen HY, Wang HS, Tung K et al (2015). Effects of gender difference and caffeine supplementation on anaerobic muscle performance. Int J Sports Med 36:974-978

32. Skinner TL, Desbrow B, Arapova J et al (2019) Women experience the same ergogenic response to caffeine as men. Med Sci Sports Exerc 51:1195-1202

33. Gunes A, Ozbey G, Vural EH et al (2009) Influence of genetic polymorphisms, smoking, gender and age on CYP1A2 activity in a Turkish population. Pharmacogenomics 10:769-778

34. Koonrungsesomboon N, Khatsri R, Wongchompoo P et al (2018) The impact of genetic polymorphisms on CYP1A2 activity in humans: a systematic review and metaanalysis. Pharmacogenomics J 18:760-768 
35. Djordjevic N, Ghotbi R, Jankovic S et al (2010) Induction of CYP1A2 by heavy coffee consumption is associated with the CYP1A2 -163C>A polymorphism. Eur J Clin Pharmacol 66:697-703

36. Lampe JW, King IB, Li S et al (2000) Brassica vegetables increase and apiaceous vegetables decrease cytochrome P450 1A2 activity in humans: changes in caffeine metabolite ratios in response to controlled vegetable diets. Carcinogenesis 21:11571162

37. Lane JD, Steege JF, Rupp SL et al (1992) Menstrual cycle effects on caffeine elimination in the human female. Eur J Clin Pharmacol 43:543-546

38. Abernethy DR, Todd EL (1985) Impairment of caffeine clearance by chronic use of low-dose oestrogen-containing oral contraceptives. Eur J Clin Pharmacol 28:425-428

39. Lara B, Gutiérrez-Hellín J, García-Bataller A et al (2020) Ergogenic effects of caffeine on peak aerobic cycling power during the menstrual cycle. Eur J Nutr $59: 2525-2534$

40. Lara B, Gutiérrez Hellín J, Ruíz-Moreno C et al (2020) Acute caffeine intake increases performance in the 15-s Wingate test during the menstrual cycle. Br J Clin Pharmacol. $86: 745-752$

41. Pickering C (2019) Caffeine, CYP1A2 genotype, and sports performance: is timing important? Ir J of Med Sci 188:349-350

42. Vistisen K, Poulsen HE, Loft S (1992) Foreign compound metabolism capacity in man measured from metabolites of dietary caffeine. Carcinogenesis 13:1561-1568

43. Galiano C, Pareja-Blanco F, Hidalgo de Mora J et al (2020) Low-velocity loss induces similar strength gains to moderate-velocity loss during resistance training. J Strength Cond Res. doi: 10.1519/JSC.0000000000003487 
44. Pareja-Blanco F, Rodríguez-Rosell D, Sánchez-Medina L et al (2017). Effects of velocity loss during resistance training on athletic performance, strength gains and muscle adaptations. Scand J Med Sci Sports 27:724-735

45. Grgic J, Pickering C. (2019) The effects of caffeine ingestion on isokinetic muscular strength: a meta-analysis. J Sci Med Sport 22:353-360

46. Grgic J, Trexler ET, Lazinica B et al (2018) Effects of caffeine intake on muscle strength and power: a systematic review and meta-analysis. J Int Soc Sports Nutr 15: 11

47. Wickham KA, Spriet LL (2018) Administration of Caffeine in Alternate Forms. Sports Med 48:79-91

48. Goldstein ER, Ziegenfuss T, Kalman D et al (2010) International society of sports nutrition position stand: caffeine and performance. J Int Soc Sports Nutr 7:5

49. Collomp K, Ahmaidi S, Chatard JC et al (1992) Benefits of caffeine ingestion on sprint performance in trained and untrained swimmers. Eur J Appl Physiol Occup Physiol 64:377-380

50. Bell DG, McLellan TM (2002) Exercise endurance 1, 3, and $6 \mathrm{~h}$ after caffeine ingestion in caffeine users and nonusers. J Appl Physiol 93:1227-1234

51. Lara B, Ruiz-Moreno C, Salinero JJ et al (2019) Time course of tolerance to the performance benefits of caffeine. PLoS ONE 14:e0210275

52. Borenstein, M, Hedges LV, Higgins JPT et al (2009) Introduction to meta-analysis. John Wiley \& Sons Ltd. Chichester.

53. Loy BD, O'Connor PJ, Lindheimer JB et al (2015) Caffeine is ergogenic for adenosine A2A receptor gene (ADORA2A) T allele homozygotes: a pilot study. J Caffeine Res $5: 73-81$ 
54. Grgic J, Pickering C, Bishop DJ et al (2020) ADORA2A C Allele Carriers Exhibit

556 Ergogenic Responses to Caffeine Supplementation. Nutrients 12:741

557 
Acknowledgments: none.

559 Conflict of interest: The authors declare that they have no competing interests. CP is a

560 former employee of DNAFit Ltd., a genetic testing company. He received no financial

561 incentives for the preparation of this manuscript.

562 Funding: none.

563

564

565

566

567

568

569

570

571

572

573

574

575

576

577 
578 Table 1. Characteristics of the participants included in the studies

\begin{tabular}{|c|c|c|c|}
\hline Study & Study sample & $\begin{array}{l}\text { Habitual caffeine } \\
\text { intake }\end{array}$ & Genotype distribution \\
\hline \multirow[t]{2}{*}{$\begin{array}{l}\text { Algrain et al. } \\
(2015)\end{array}$} & \multirow{2}{*}{$\begin{array}{l}\text { Recreationally active } \\
\text { men and women }(n= \\
20)\end{array}$} & \multirow[t]{2}{*}{$<300 \mathrm{mg} /$ day } & $\begin{array}{l}\text { AA genotype, } n=11 \text { (age: } 24 \pm \\
2 \text { years; mass: } 76 \pm 5 \mathrm{~kg} \text { ) }\end{array}$ \\
\hline & & & $\begin{array}{l}\text { AC/CC genotype, } n=9 \text { (age: } 26 \\
\pm 1 \text { years; mass: } 77 \pm 6 \mathrm{~kg})\end{array}$ \\
\hline \multirow[t]{2}{*}{$\begin{array}{l}\text { Carswell et } \\
\text { al. }(2020)\end{array}$} & \multirow[t]{2}{*}{$\begin{array}{l}\text { Healthy active men } \\
\text { and women }(n=18)\end{array}$} & \multirow{2}{*}{$\begin{array}{l}13 \text { participants were } \\
\text { "low" users ( } 0-150 \\
\text { mg/day), } 2 \text { participants } \\
\text { were "moderate" users } \\
\text { (151-300 mg/day), and } \\
3 \text { participants were } \\
\text { "high" users ( }>300 \\
\text { mg/day) }\end{array}$} & $\begin{array}{l}\text { AA genotype, } n=10(\text { age: } 23 \pm \\
3 \text { years; mass: } 68 \pm 11 \mathrm{~kg})\end{array}$ \\
\hline & & & $\begin{array}{l}\text { AC/CC genotype, } n=8 \text { (age: } 25 \\
\pm 5 \text { years; mass: } 74 \pm 8 \mathrm{~kg})\end{array}$ \\
\hline \multirow[t]{2}{*}{$\begin{array}{l}\text { Davenport et } \\
\text { al. }(2020)\end{array}$} & \multirow{2}{*}{$\begin{array}{l}\text { Well-trained male and } \\
\text { female cyclists }(n= \\
13)\end{array}$} & \multirow[t]{2}{*}{$\geq 50 \mathrm{mg} /$ day } & $\begin{array}{l}\text { AA genotype, } n=7 \text { (age: } 28 \pm 2 \\
\text { years; mass: } 71 \pm 2 \mathrm{~kg} \text { ) }\end{array}$ \\
\hline & & & $\begin{array}{l}\text { AC genotype, } n=6 \text { (age: } 28 \pm 2 \\
\text { years; mass: } 71 \pm 2 \mathrm{~kg} \text { ) }\end{array}$ \\
\hline \multirow[t]{2}{*}{$\begin{array}{l}\text { Giersch et al. } \\
(2018)\end{array}$} & \multirow[t]{2}{*}{$\begin{array}{l}\text { Recreationally-trained } \\
\text { male cyclists }(n=20)\end{array}$} & \multirow{2}{*}{$\begin{array}{l}93 \pm 111 \mathrm{mg} / \text { day }(\mathrm{AA} \\
\text { genotype); } 92 \pm 137 \\
\text { mg/day (AC/CC } \\
\text { genotype) }\end{array}$} & $\begin{array}{l}\text { AA genotype, } n=8 \text { (age: } 24 \pm 8 \\
\text { years; mass: } 72 \pm 9 \mathrm{~kg} \text { ) }\end{array}$ \\
\hline & & & $\begin{array}{l}\text { AC/CC genotype, } n=12 \text { (age: } \\
25 \pm 7 \text { years; mass: } 75 \pm 12 \mathrm{~kg} \text { ) }\end{array}$ \\
\hline \multirow[t]{2}{*}{$\begin{array}{l}\text { Grgic et al. } \\
(2020)\end{array}$} & \multirow[t]{2}{*}{$\begin{array}{l}\text { Resistance-trained } \\
\text { men }(n=22)\end{array}$} & \multirow{2}{*}{$\begin{array}{l}133 \pm 123 \mathrm{mg} / \text { day }(\mathrm{AA} \\
\text { genotype }), 117 \pm 68 \\
\text { mg/day }(\mathrm{AC} / \mathrm{CC} \\
\text { genotype) }\end{array}$} & $\begin{array}{l}\text { AA genotype, } n=13 \text { (age: } 27 \pm \\
6 \text { years; mass: } 78 \pm 7 \mathrm{~kg} \text { ) }\end{array}$ \\
\hline & & & $\begin{array}{l}\text { AC/CC genotype, } n=9 \text { (age: } 30 \\
\pm 4 \text { years; mass: } 81 \pm 15 \mathrm{~kg})\end{array}$ \\
\hline \multirow[t]{3}{*}{$\begin{array}{l}\text { Guest et al. } \\
(2018)\end{array}$} & \multirow{3}{*}{$\begin{array}{l}\text { Male athletes from } \\
\text { endurance, power, or } \\
\text { mixed-sports }(n= \\
101)\end{array}$} & \multirow{3}{*}{$\begin{array}{l}\text { For sport } \\
61 \pm 13 \mathrm{mg} / \text { day (AA } \\
\text { genotype), } 89 \pm 17 \\
\mathrm{mg} / \text { day (AC genotype), } \\
80 \pm 74 \mathrm{mg} / \text { day (CC } \\
\text { genotype) } \\
\text { Dietary } \\
87 \pm 18 \mathrm{mg} / \text { day (AA } \\
\text { genotype), } 80 \pm 20 \\
\mathrm{mg} / \text { day (AC genotype), } \\
38 \pm 24 \mathrm{mg} / \text { day (CC } \\
\text { genotype) }\end{array}$} & $\begin{array}{l}\text { AA genotype, } n=49 \text { (age: } 24 \pm \\
4 \text { years; mass: } 80 \pm 12 \mathrm{~kg} \text { ) }\end{array}$ \\
\hline & & & $\begin{array}{l}\text { AC genotype, } n=44 \text { (age: } 25 \pm \\
5 \text { years; mass: } 80 \pm 10 \mathrm{~kg} \text { ) }\end{array}$ \\
\hline & & & $\begin{array}{l}\text { CC genotype, } n=8 \text { (age: } 25 \pm 5 \\
\text { years; mass: } 93 \pm 25 \mathrm{~kg} \text { ) }\end{array}$ \\
\hline \multirow[t]{2}{*}{$\begin{array}{l}\text { Klein et al. } \\
(2012)\end{array}$} & \multirow{2}{*}{$\begin{array}{l}\text { Collegiate male and } \\
\text { female tennis players } \\
(n=16)\end{array}$} & \multirow{2}{*}{$\begin{array}{l}104 \pm 34 \mathrm{mg} / \text { day }(\mathrm{AA} \\
\text { genotype), } 92 \pm 64 \\
\text { mg/day (AC/CC } \\
\text { genotype) }\end{array}$} & $\begin{array}{l}\text { AA genotype, } n=7 \text { (age: } 21 \pm 2 \\
\text { years; mass: } 71 \pm 13 \mathrm{~kg} \text { ) }\end{array}$ \\
\hline & & & $\begin{array}{l}\text { AC/CC genotype, } n=9 \text { (age: } 21 \\
\pm 2 \text { years; mass: } 71 \pm 13 \mathrm{~kg} \text { ) }\end{array}$ \\
\hline \multirow[t]{2}{*}{$\begin{array}{l}\text { McGrath } \\
(2015)\end{array}$} & \multirow{2}{*}{$\begin{array}{l}\text { Well trained male } \\
\text { endurance athletes }(n \\
=11)\end{array}$} & \multirow{2}{*}{$\begin{array}{l}27 \% \text { "low" users, } 45 \% \\
\text { "moderate" users, and } \\
27 \% \text { "high" habitual } \\
\text { caffeine users }\end{array}$} & $\begin{array}{l}\text { AA genotype, } n=6 \text { (age: } 31 \pm 3 \\
\text { years; mass: } 77 \pm 4 \mathrm{~kg} \text { ) }\end{array}$ \\
\hline & & & $\begin{array}{l}\text { AC/CC genotype, } n=5 \text { age: } 31 \\
\pm 3 \text { years; mass: } 77 \pm 4 \mathrm{~kg})\end{array}$ \\
\hline
\end{tabular}




\begin{tabular}{|c|c|c|c|}
\hline \multirow[t]{2}{*}{$\begin{array}{l}\text { Muñoz et al. } \\
(2020)\end{array}$} & \multirow{2}{*}{$\begin{array}{l}\text { Professional male and } \\
\text { female handball } \\
\text { players }(n=31)\end{array}$} & \multirow[t]{2}{*}{$60 \pm 25 \mathrm{mg} /$ day } & $\begin{array}{l}\text { AA genotype, } n=14 \text { (age: } 24 \pm \\
3 \text { years; mass: } 79 \pm 16 \mathrm{~kg})\end{array}$ \\
\hline & & & $\begin{array}{l}\text { AC/CC genotype, } n=17 \text { (age: } \\
24 \pm 3 \text { years; mass: } 79 \pm 16 \mathrm{~kg} \text { ) }\end{array}$ \\
\hline \multirow[t]{2}{*}{$\begin{array}{l}\text { Pataky et al. } \\
(2016)\end{array}$} & \multirow{2}{*}{$\begin{array}{l}\text { Recreationally-trained } \\
\text { male and female } \\
\text { cyclists }(n=38)\end{array}$} & \multirow[t]{2}{*}{ Average of $70 \mathrm{mg} /$ day } & $\begin{array}{l}\text { AA genotype, } n=21 \text { (age: } 20 \pm \\
1 \text { years; mass: } 68 \pm 13 \mathrm{~kg} \text { ) }\end{array}$ \\
\hline & & & $\begin{array}{l}\text { AC genotype, } n=17 \text { (age: } 21 \pm \\
1 \text { years; mass: } 74 \pm 8 \mathrm{~kg} \text { ) }\end{array}$ \\
\hline \multirow[t]{2}{*}{$\begin{array}{l}\text { Potgieter } \\
(2013)\end{array}$} & \multirow[t]{2}{*}{$\begin{array}{l}\text { Male and female } \\
\text { triathletes }(n=26)\end{array}$} & \multirow[t]{2}{*}{$413 \pm 505 \mathrm{mg} / \mathrm{day}$} & $\begin{array}{l}\text { AA genotype, } n=16 \text { (age: } 38 \pm \\
11 \text { years; mass: } 69 \pm 11 \mathrm{~kg} \text { ) }\end{array}$ \\
\hline & & & $\begin{array}{l}\text { AC/CC genotype, } n=10(\text { age: } \\
38 \pm 11 \text { years; mass: } 69 \pm 11 \mathrm{~kg})\end{array}$ \\
\hline \multirow[t]{2}{*}{$\begin{array}{l}\text { Puente et al. } \\
(2018)\end{array}$} & \multirow{2}{*}{$\begin{array}{l}\text { Male and female elite } \\
\text { basketball players }(n= \\
19)\end{array}$} & \multirow[t]{2}{*}{$<100 \mathrm{mg}$ per day } & $\begin{array}{l}\text { AA genotype, } n=10 \text { (age: } 27 \pm \\
4 \text { years; mass: } 84 \pm 19 \mathrm{~kg} \text { ) }\end{array}$ \\
\hline & & & $\begin{array}{l}\text { AC/CC genotype, } n=9 \text { (age: } 29 \\
\pm 6 \text { years; mass: } 78 \pm 15 \mathrm{~kg})\end{array}$ \\
\hline \multirow[t]{2}{*}{$\begin{array}{l}\text { Rahimi } \\
(2018)\end{array}$} & \multirow[t]{2}{*}{$\begin{array}{l}\text { Resistance-trained } \\
\text { men }(n=30)\end{array}$} & \multirow{2}{*}{$\begin{array}{l}\text { "Light caffeine } \\
\text { consumers" }(<70 \\
\text { mg/day) }\end{array}$} & $\begin{array}{l}\text { AA genotype, } n=14 \text { (age: } 21 \pm \\
2 \text { years; mass: } 79 \pm 19 \mathrm{~kg} \text { ) }\end{array}$ \\
\hline & & & $\begin{array}{l}\text { AC/CC genotype, } n=16 \text { (age: } \\
22 \pm 5 \text { years; mass: } 77 \pm 11 \mathrm{~kg} \text { ) }\end{array}$ \\
\hline \multirow[t]{2}{*}{$\begin{array}{l}\text { Salinero et al. } \\
(2017)\end{array}$} & \multirow{2}{*}{$\begin{array}{l}\text { Recreationally active } \\
\text { men and women }(n= \\
21)\end{array}$} & \multirow[t]{2}{*}{$<60 \mathrm{mg}$ per day } & $\begin{array}{l}\text { AA genotype, } n=5(\text { age: } 29 \pm 7 \\
\text { years; mass: } 69 \pm 10 \mathrm{~kg})\end{array}$ \\
\hline & & & $\begin{array}{l}\text { AC/CC genotype, } n=16(\text { age: } \\
29 \pm 7 \text { years; mass: } 69 \pm 10 \mathrm{~kg})\end{array}$ \\
\hline $\begin{array}{l}\text { Southward } \\
\text { (2016) }\end{array}$ & $\begin{array}{l}\text { Recreationally trained } \\
\text { male athletes }(n=14)\end{array}$ & $\begin{array}{l}\text { "All participants were } \\
\text { regular users of } \\
\text { caffeine" }\end{array}$ & $\begin{array}{l}\text { AC genotype, } n=14 \text { (age: } 27 \pm \\
8 \text { years; mass: } 77 \pm 9 \mathrm{~kg} \text { ) }\end{array}$ \\
\hline \multirow[t]{3}{*}{$\begin{array}{l}\text { Spineli et al. } \\
(2020)\end{array}$} & \multirow{3}{*}{$\begin{array}{l}\text { Male adolescents } \\
\text { engaged in } \\
\text { competitive sports }(n \\
=100)\end{array}$} & \multirow{3}{*}{$\begin{array}{l}42 \pm 39 \mathrm{mg} / \text { day (AA } \\
\text { genotype), } 59 \pm 45 \\
\text { mg/day (AC genotype), } \\
33 \text { mg/day (CC } \\
\text { genotype) }\end{array}$} & $\begin{array}{l}\text { AA genotype, } n=49 \text { (age: } 15 \pm \\
2 \text { years; mass: } 58 \pm 10 \mathrm{~kg} \text { ) }\end{array}$ \\
\hline & & & $\begin{array}{l}\text { AC genotype, } n=42(\text { age: } 16 \pm \\
2 \text { years; mass: } 58 \pm 13 \mathrm{~kg})\end{array}$ \\
\hline & & & $\begin{array}{l}\text { CC genotype, } n=9 \text { (age: } 16 \\
\text { years; mass: } 68 \mathrm{~kg})^{\mathrm{a}}\end{array}$ \\
\hline \multirow[t]{2}{*}{$\begin{array}{l}\text { Womack et } \\
\text { al. }(2012)\end{array}$} & \multirow[t]{2}{*}{$\begin{array}{l}\text { Male competitive } \\
\text { cyclists }(n=35)\end{array}$} & \multirow{2}{*}{$\begin{array}{l}86 \pm 107 \mathrm{mg} / \text { day }(\mathrm{AA} \\
\text { genotype), } 87 \pm 145 \\
\text { mg/day (AC/CC } \\
\text { genotype) }\end{array}$} & $\begin{array}{l}\text { AA genotype, } n=16 \text { (age: } 24 \pm \\
7 \text { years; mass: } 74 \pm 13 \mathrm{~kg} \text { ) }\end{array}$ \\
\hline & & & $\begin{array}{l}\text { AC/CC genotype, } n=19 \text { (age: } \\
26 \pm 8 \text { years; mass: } 74 \pm 12 \mathrm{~kg} \text { ) }\end{array}$ \\
\hline
\end{tabular}


Table 2. Summary of the caffeine intake protocols, exercise task(s), and main findings from the studies included in the review

\begin{tabular}{|c|c|c|c|c|}
\hline Study & $\begin{array}{l}\text { Caffeine } \\
\text { supplementation } \\
\text { protocol }\end{array}$ & Exercise task(s) & Main findings & Effect sizes \\
\hline $\begin{array}{l}\text { Algrain et } \\
\text { al. (2015) }\end{array}$ & $\begin{array}{l}255 \mathrm{mg} \text { of caffeine } \\
\text { consumed in a } \\
\text { chewing gum } 15- \\
\text { minutes before } \\
\text { starting the exercise } \\
\text { session }\end{array}$ & $\begin{array}{l}15 \text {-min of cycling } \\
\text { at } 75 \% \mathrm{VO}_{2 \max }, 10 \\
\text { min of rest, and } 15- \\
\text { min cycling time } \\
\text { trial }\end{array}$ & $\begin{array}{l}\text { No main effect of } \\
\text { caffeine, and no } \\
\text { caffeine } \times \text { genotype } \\
\text { interaction }\end{array}$ & $\begin{array}{l}\text { AA genotype: } 0.16 \\
\text { AC/CC genotype: } 0.29\end{array}$ \\
\hline $\begin{array}{l}\text { Carswell } \\
\text { et al. } \\
(2020)\end{array}$ & $\begin{array}{l}3 \mathrm{mg} / \mathrm{kg} \text { of caffeine } \\
\text { consumed in } \\
\text { capsules } 70 \text {-minutes } \\
\text { before starting the } \\
\text { exercise session }\end{array}$ & $\begin{array}{l}15 \text {-min cycling } \\
\text { time trial }\end{array}$ & $\begin{array}{l}\text { A main effect of } \\
\text { caffeine, but no } \\
\text { caffeine } \times \text { genotype } \\
\text { interaction }\end{array}$ & Data not presented \\
\hline $\begin{array}{l}\text { Davenport } \\
\text { et al. } \\
(2020)\end{array}$ & $\begin{array}{l}200 \mathrm{mg} \text { of caffeine } \\
\text { consumed in a drink } \\
\text { either } 35 \text {-minutes } \\
\text { before exercise, } \\
\text { before } 30 \text {-minutes of } \\
\text { steady-state cycling, } \\
\text { or immediately } \\
\text { before a } 15 \text {-minute } \\
\text { cycling time trial }^{\text {a }}\end{array}$ & $\begin{array}{l}30 \text { min of steady- } \\
\text { state cycling } \\
\text { followed by and a } \\
15 \text {-minute cycling } \\
\text { time trial }\end{array}$ & $\begin{array}{l}\text { A main effect of } \\
\text { caffeine when } \\
\text { caffeine was } \\
\text { ingested } 35- \\
\text { minutes before the } \\
\text { start of the exercise } \\
\text { session, but no } \\
\text { caffeine } \times \text { genotype } \\
\text { interaction }\end{array}$ & $\begin{array}{l}\text { 35-minutes before } \\
\text { exercise } \\
\text { Whole sample: } 0.35 \\
\text { Before } 30 \text {-minutes of } \\
\text { steady-state cycling } \\
\text { Whole sample: } 0.17 \\
\text { Before a 15-minute } \\
\text { cycling time trial } \\
\text { Whole sample: } 0.06\end{array}$ \\
\hline $\begin{array}{l}\text { Giersch et } \\
\text { al. (2018) }\end{array}$ & $\begin{array}{l}6 \mathrm{mg} / \mathrm{kg} \text { of caffeine } \\
\text { consumed in } \\
\text { capsules } 60 \text {-minutes } \\
\text { before starting the } \\
\text { exercise session }\end{array}$ & $\begin{array}{l}\text { 3-km cycling time } \\
\text { trial }\end{array}$ & $\begin{array}{l}\text { A main effect of } \\
\text { caffeine, but no } \\
\text { caffeine } \times \text { genotype } \\
\text { interaction }\end{array}$ & $\begin{array}{l}\text { AA genotype: } 0.37 \\
\text { AC/CC genotype: } 0.25\end{array}$ \\
\hline $\begin{array}{l}\text { Grgic et } \\
\text { al. }(2020)\end{array}$ & $\begin{array}{l}3 \mathrm{mg} / \mathrm{kg} \text { of caffeine } \\
\text { consumed in } \\
\text { capsules } 60 \text {-minutes } \\
\text { before starting the } \\
\text { exercise session }\end{array}$ & $\begin{array}{l}\text { Movement velocity } \\
\text { and power in the } \\
\text { bench press with } \\
\text { different loads, one } \\
\text { set of bench press } \\
\text { with } 85 \% 1 \mathrm{RM} \\
\text { performed to } \\
\text { muscle failure, } \\
\text { CMJ, and 30- } \\
\text { second Wingate }\end{array}$ & $\begin{array}{l}\text { A main effect of } \\
\text { caffeine in all } \\
\text { exercise tests, but } \\
\text { no caffeine } \times \\
\text { genotype } \\
\text { interaction }\end{array}$ & $\begin{array}{l}\text { Movement velocity and } \\
\text { power in the bench press } \\
\text { AA genotype: } 0.14-0.69 \\
\text { AC/CC genotype: } 0.23- \\
0.85 \\
\text { Muscle endurance and } \\
\text { velocity } \\
\text { AA genotype: } 0.23-0.66 \\
\text { AC/CC genotype: } 0.33- \\
1.27 \\
\text { CMJ } \\
\text { AA genotype: } 0.19 \\
\text { AC/CC genotype: } 0.15 \\
\text { Power output in the } \\
\text { Wingate } \\
\text { AA genotype: } 0.31-0.57 \\
\text { AC/CC genotype: } 0.34- \\
0.43\end{array}$ \\
\hline
\end{tabular}




\begin{tabular}{|c|c|c|c|c|}
\hline $\begin{array}{l}\text { Guest et } \\
\text { al. (2018) }\end{array}$ & $\begin{array}{l}2 \text { or } 4 \mathrm{mg} / \mathrm{kg} \text { of } \\
\text { caffeine consumed } \\
\text { in capsules } 60- \\
\text { minutes before } \\
\text { starting the exercise } \\
\text { session }\end{array}$ & $\begin{array}{l}\text { 10-km cycling time } \\
\text { trial }\end{array}$ & $\begin{array}{l}\text { A main effect of } \\
\text { caffeine and } \\
\text { caffeine } \times \text { genotype } \\
\text { interaction, } \\
\text { whereby } \\
\text { participants with } \\
\text { the AA genotype } \\
\text { improved } \\
\text { performance } \\
\text { following caffeine } \\
\text { ingestion (both } 2 \\
\text { and } 4 \text { mg/kg), those } \\
\text { with the AC } \\
\text { genotype did not } \\
\text { improve } \\
\text { performance with } \\
\text { any of the caffeine } \\
\text { doses, and } \\
\text { performance of } \\
\text { those with the CC } \\
\text { genotype was } \\
\text { worse with the } \\
\text { ingestion of } 4 \\
\text { kg/mg but not } 2 \\
\text { mg/kg of caffeine }\end{array}$ & $\begin{array}{l}2 \mathrm{mg} / \mathrm{kg} \\
\text { AA genotype: } 0.33 \\
\text { AC genotype: } 0.07 \\
\text { CC genotype: (data not } \\
\text { presented) } \\
4 \mathrm{mg} / \mathrm{kg} \\
\text { AA genotype: } 0.49 \\
\text { AC genotype: } 0.20 \\
\text { CC genotype: }-1.35\end{array}$ \\
\hline $\begin{array}{l}\text { Klein et al. } \\
(2012)\end{array}$ & $\begin{array}{l}6 \mathrm{mg} / \mathrm{kg} \text { of caffeine } \\
\text { consumed in } \\
\text { capsules } 60 \text {-minutes } \\
\text { before starting the } \\
\text { exercise session }\end{array}$ & $\begin{array}{l}45 \text {-minutes of } \\
\text { intermittent } \\
\text { treadmill exercise } \\
\text { followed } \\
\text { by a tennis skill test }\end{array}$ & $\begin{array}{l}\text { A main effect of } \\
\text { caffeine, but no } \\
\text { caffeine } \times \text { genotype } \\
\text { interaction }\end{array}$ & $\begin{array}{l}\text { AA genotype: } 0.48 \\
\text { AC/CC genotype: } 0.62\end{array}$ \\
\hline $\begin{array}{l}\text { McGrath } \\
(2015)\end{array}$ & $\begin{array}{l}5 \mathrm{mg} / \mathrm{kg} \text { of caffeine } \\
\text { consumed in } \\
\text { capsules } 60 \text {-minutes } \\
\text { before starting the } \\
\text { exercise session }\end{array}$ & $\begin{array}{l}\text { 115-minutes of } \\
\text { steady-state cycling } \\
\text { followed by a } 30- \\
\text { minute time trial }\end{array}$ & $\begin{array}{l}\text { A main effect of } \\
\text { caffeine, but no } \\
\text { caffeine } \times \text { genotype } \\
\text { interaction }\end{array}$ & Whole sample: 0.59 \\
\hline $\begin{array}{l}\text { Muñoz et } \\
\text { al. (2020) }\end{array}$ & $\begin{array}{l}3 \mathrm{mg} / \mathrm{kg} \text { of caffeine } \\
\text { consumed in } \\
\text { capsules } 60 \text {-minutes } \\
\text { before starting the } \\
\text { exercise session }\end{array}$ & $\begin{array}{l}\text { CMJ, sprint } \\
\text { velocity test, } \\
\text { modified agility t- } \\
\text { test, isometric } \\
\text { handgrip strength, } \\
\text { ball throw from 7- } \\
\text { m, ball throw from } \\
\text { 7-m with a } \\
\text { goalkeeper, ball } \\
\text { throw from 9-m, } \\
\text { and ball throw } \\
\text { from 9-m with a } \\
\text { goalkeeper }\end{array}$ & $\begin{array}{l}\text { A main effect of } \\
\text { caffeine for CMJ } \\
\text { height, time in the } \\
\text { sprint velocity test, } \\
\text { and ball throw } \\
\text { velocity from 9-m, } \\
\text { but no caffeine } \times \\
\text { genotype } \\
\text { interaction. No } \\
\text { main effect of } \\
\text { caffeine for time to } \\
\text { complete the } \\
\text { modified agility t- } \\
\text { test, isometric } \\
\text { handgrip strength, }\end{array}$ & $\begin{array}{l}\text { CMJ } \\
\text { AA genotype: } 0.28 \\
\text { AC/CC genotype: } 0.15 \\
\text { Sprint velocity test } \\
\text { AA genotype: } 0.84 \\
\text { AC/CC genotype: } 0.15 \\
\text { Modified agility } t \text {-test } \\
\text { AA genotype: } 0.03 \\
\text { AC/CC genotype: }-0.05 \\
\text { Isometric handgrip } \\
\text { strength } \\
\text { AA genotype: } 0.00 \\
\text { AC/CC genotype: } 0.23 \\
\text { Ball throw from } 7-m \\
\text { AA genotype: } 0.34\end{array}$ \\
\hline
\end{tabular}




\begin{tabular}{|c|c|c|c|c|}
\hline & & & $\begin{array}{l}\text { ball throw velocity } \\
\text { from } 7 \text {-m with a } \\
\text { goalkeeper, ball } \\
\text { throw velocity } \\
\text { from 9-m with a } \\
\text { goalkeeper, and no } \\
\text { caffeine } \times \text { genotype } \\
\text { interaction. No } \\
\text { main effect of } \\
\text { caffeine for ball } \\
\text { throw velocity } \\
\text { from } 7 \text {-m, but a } \\
\text { caffeine } \times \text { genotype } \\
\text { interaction whereby } \\
\text { participants with } \\
\text { the AA genotype } \\
\text { improved } \\
\text { performance } \\
\text { following caffeine } \\
\text { ingestion while } \\
\text { those with the } \\
\text { AC/CC genotype } \\
\text { did not }\end{array}$ & $\begin{array}{l}\text { AC/CC genotype: }-0.02 \\
\text { Ball throw from } 7-m \text { with } \\
\text { a goalkeeper } \\
\text { AA genotype: } 0.39 \\
\text { AC/CC genotype: }-0.23 \\
\text { Ball throw from 9-m } \\
\text { AA genotype: } 0.40 \\
\text { AC/CC genotype: } 0.22 \\
\text { Ball throw from 9-m with } \\
\text { a goalkeeper } \\
\text { AA genotype: } 0.47 \\
\text { AC/CC genotype: } 0.05\end{array}$ \\
\hline $\begin{array}{l}\text { Pataky et } \\
\text { al. }(2016)\end{array}$ & $\begin{array}{l}6 \mathrm{mg} / \mathrm{kg} \text { of caffeine } \\
\text { consumed in } \\
\text { capsules } 60 \text {-minutes } \\
\text { before starting the } \\
\text { exercise session, } \\
\text { with or without } \\
\text { additional caffeine } \\
\text { mouth rinsing }\end{array}$ & $\begin{array}{l}\text { 3-km cycling time } \\
\text { trial }\end{array}$ & $\begin{array}{l}\text { A main effect of } \\
\text { caffeine when } \\
\text { caffeine ingestion } \\
\text { was combined with } \\
\text { mouth rinsing; } \\
\text { using MBI, the } \\
\text { effects favored the } \\
\text { AC genotype, but } \\
\text { the effect was not } \\
\text { statistically } \\
\text { significant ( } p= \\
0.12 \text { ) }\end{array}$ & Data not presented \\
\hline $\begin{array}{l}\text { Potgieter } \\
(2013)\end{array}$ & $\begin{array}{l}6 \mathrm{mg} / \mathrm{kg} \text { of caffeine } \\
\text { consumed in } \\
\text { capsules } 60 \text {-minutes } \\
\text { before starting the } \\
\text { exercise session }\end{array}$ & $\begin{array}{l}\text { Olympic-distance } \\
\text { triathlons }\end{array}$ & $\begin{array}{l}\text { A main effect of } \\
\text { caffeine, but no } \\
\text { caffeine } \times \text { genotype } \\
\text { interaction }\end{array}$ & Whole sample: 0.10 \\
\hline $\begin{array}{l}\text { Puente et } \\
\text { al. (2018) }\end{array}$ & $\begin{array}{l}3 \mathrm{mg} / \mathrm{kg} \text { of caffeine } \\
\text { consumed in } \\
\text { capsules } 60 \text {-minutes } \\
\text { before starting the } \\
\text { exercise session }\end{array}$ & $\begin{array}{l}\text { Abalakov jump } \\
\text { test and the } \\
\text { "Change-of- } \\
\text { Direction and } \\
\text { Acceleration Test" } \\
\text { with and without } \\
\text { the ball }\end{array}$ & $\begin{array}{l}\text { A main effect of } \\
\text { caffeine for } \\
\text { Abalakov jump } \\
\text { height, but no } \\
\text { caffeine } \times \text { genotype } \\
\text { interaction; no } \\
\text { main effect of } \\
\text { caffeine for sprint } \\
\text { time in the } \\
\text { "Change-of- }\end{array}$ & $\begin{array}{l}\text { Abalakov jump } \\
\text { AA genotype: } 0.15 \\
\text { AC/CC genotype: } 0.14 \\
\text { "Change-of-Direction } \\
\text { and Acceleration Test" } \\
\text { without the ball } \\
\text { AA genotype: } 0.12 \\
\text { AC/CC genotype: }-0.06\end{array}$ \\
\hline
\end{tabular}




\begin{tabular}{|c|c|c|c|c|}
\hline & & & $\begin{array}{l}\text { Direction and } \\
\text { Acceleration Test" } \\
\text { with or without the } \\
\text { ball and no caffeine } \\
\times \text { genotype } \\
\text { interaction }\end{array}$ & $\begin{array}{l}\text { "Change-of-Direction } \\
\text { and Acceleration Test" } \\
\text { with the ball } \\
\text { AA genotype: } 0.44 \\
\text { AC/CC genotype: } 0.0\end{array}$ \\
\hline $\begin{array}{l}\text { Rahimi } \\
\text { (2018) }\end{array}$ & $\begin{array}{l}6 \mathrm{mg} / \mathrm{kg} \text { of caffeine } \\
\text { consumed in } \\
\text { capsules } 60 \text {-minutes } \\
\text { before starting the } \\
\text { exercise session }\end{array}$ & $\begin{array}{l}3 \text { sets performed to } \\
\text { muscle failure with } \\
85 \% 1 \mathrm{RM} \text { in the } \\
\text { bench press, leg } \\
\text { press, seated row, } \\
\text { and shoulder press }\end{array}$ & $\begin{array}{l}\text { A main effect of } \\
\text { caffeine and } \\
\text { caffeine } \times \text { genotype } \\
\text { interaction in all } \\
\text { exercises, whereby } \\
\text { participants with } \\
\text { the AA genotype } \\
\text { improved } \\
\text { performance } \\
\text { following caffeine } \\
\text { ingestion while } \\
\text { those with the } \\
\text { AC/CC genotype } \\
\text { did not }\end{array}$ & $\begin{array}{l}\text { Bench press } \\
\text { AA genotype: } 0.88-1.87 \\
\text { AC/CC genotype: }-0.05 \\
\text { to } 0.09 \\
\text { Leg press } \\
\text { AA genotype: } 0.48-1.22 \\
\text { AC/CC genotype: }-0.12 \\
\text { to } 0.44 \\
\text { Seated row } \\
\text { AA genotype: } 0.87-1.30 \\
\text { AC/CC genotype: } 0.17- \\
0.27 \\
\text { Shoulder press } \\
\text { AA genotype: } 0.57-1.86 \\
\text { AC/CC genotype: } 0.12- \\
0.48\end{array}$ \\
\hline $\begin{array}{l}\text { Salinero et } \\
\text { al. (2017) }\end{array}$ & $\begin{array}{l}3 \mathrm{mg} / \mathrm{kg} \text { of caffeine } \\
\text { consumed in } \\
\text { capsules } 60 \text {-minutes } \\
\text { before starting the } \\
\text { exercise session }\end{array}$ & 30-second Wingate & $\begin{array}{l}\text { A main effect of } \\
\text { caffeine for peak } \\
\text { and mean power, } \\
\text { but no caffeine } \times \\
\text { genotype } \\
\text { interaction }\end{array}$ & $\begin{array}{l}\text { Peak power } \\
\text { AA genotype: } 0.04 \\
\text { AC/CC genotype: } 0.15 \\
\text { Mean power } \\
\text { AA genotype: } 0.07 \\
\text { AC/CC genotype: } 0.10\end{array}$ \\
\hline $\begin{array}{l}\text { Southward } \\
\text { (2016) }\end{array}$ & $\begin{array}{l}6 \mathrm{mg} / \mathrm{kg} \text { of caffeine } \\
\text { consumed in } \\
\text { capsules } 60 \text {-minutes } \\
\text { before starting the } \\
\text { exercise session }\end{array}$ & $\begin{array}{l}\text { 10-km running } \\
\text { time trial, } \\
\text { isokinetic knee } \\
\text { extension, SJ and } \\
\text { CMJ }\end{array}$ & $\begin{array}{l}\text { A main effect of } \\
\text { caffeine for } \\
\text { eccentric knee } \\
\text { extensor torque and } \\
\text { SJ height; no } \\
\text { significant } \\
\text { difference for the } \\
\text { 10-km time trial, } \\
\text { concentric knee } \\
\text { extensor torque and } \\
\text { CMJ height }\end{array}$ & $\begin{array}{l}\text { 10-km running time trial } \\
\text { AC genotype: } 0.34 \\
\text { Concentric knee extensor } \\
\text { torque } \\
\text { AC genotype: } 0.25 \\
\text { Eccentric knee extensor } \\
\text { torque } \\
\text { AC genotype: } 0.44 \\
\text { SJ height } \\
\text { AC genotype: } 0.33 \\
\text { CMJ height } \\
\text { AC genotype: } 0.17\end{array}$ \\
\hline $\begin{array}{l}\text { Spineli et } \\
\text { al. (2020) }\end{array}$ & $\begin{array}{l}6 \mathrm{mg} / \mathrm{kg} \text { of caffeine } \\
\text { consumed in } \\
\text { capsules } 60 \text {-minutes } \\
\text { before starting the } \\
\text { exercise session }\end{array}$ & $\begin{array}{l}\text { CMJ, spike jump, } \\
\text { agility test, } \\
\text { isometric handgrip } \\
\text { strength, push-up, } \\
\text { sit-up, and Yo-Yo } \\
\text { IR1 }\end{array}$ & $\begin{array}{l}\text { A main effect of } \\
\text { caffeine for push- } \\
\text { up and sit-up } \\
\text { repetitions and } \\
\text { distance covered in } \\
\text { the Yo-Yo IR1, but } \\
\text { no caffeine } \times \\
\text { genotype } \\
\text { interaction. No } \\
\text { main effect and no }\end{array}$ & $\begin{array}{l}C M J \\
\text { AA genotype: } 0.11 \\
\text { AC genotype: } 0.13 \\
\text { CC genotype: } 0.04 \\
\text { Spike jump } \\
\text { AA genotype: } 0.14 \\
\text { AC genotype: } 0.05 \\
\text { CC genotype: } 0.01 \\
\text { Agility test } \\
\text { AA genotype: } 0.10\end{array}$ \\
\hline
\end{tabular}




\begin{tabular}{|c|c|c|c|c|}
\hline & & & $\begin{array}{l}\text { caffeine } \times \text { genotype } \\
\text { interaction for CMJ } \\
\text { height, spike jump } \\
\text { height, and time in } \\
\text { the agility test }\end{array}$ & $\begin{array}{l}\text { AC genotype: } 0.07 \\
\text { CC genotype: }-0.37 \\
\text { Isometric handgrip } \\
\text { strength } \\
\text { AA genotype: } 0.17 \\
\text { AC genotype: } 0.07 \\
\text { CC genotype: } 0.06 \\
\text { Push-up } \\
\text { AA genotype: } 0.09 \\
\text { AC genotype: } 0.24 \\
\text { CC genotype: } 0.36 \\
\text { Sit-up } \\
\text { AA genotype: } 0.24 \\
\text { AC genotype: } 0.32 \\
\text { CC genotype: } 0.28 \\
\text { Yo-Yo IR } 1 \\
\text { AA genotype: } 0.31 \\
\text { AC genotype: } 0.36 \\
\text { CC genotype: } 0.12\end{array}$ \\
\hline $\begin{array}{l}\text { Womack } \\
\text { et al. } \\
(2012)\end{array}$ & $\begin{array}{l}6 \mathrm{mg} / \mathrm{kg} \text { of caffeine } \\
\text { consumed in } \\
\text { capsules } 60 \text {-minutes } \\
\text { before starting the } \\
\text { exercise session }\end{array}$ & $\begin{array}{l}40-\mathrm{km} \text { cycling time } \\
\text { trial }\end{array}$ & $\begin{array}{l}\text { A main effect of } \\
\text { caffeine and } \\
\text { caffeine } \times \text { genotype } \\
\text { interaction, } \\
\text { whereby caffeine } \\
\text { ingestion improved } \\
\text { performance by a } \\
\text { greater magnitude } \\
\text { in the AA genotype } \\
\text { in comparison with } \\
\text { the AC/CC } \\
\text { genotype }\end{array}$ & $\begin{array}{l}\text { AA genotype: } 0.67 \\
\text { AC/CC genotype: } 0.34\end{array}$ \\
\hline \multicolumn{5}{|c|}{$\begin{array}{l}\text { SJ: squat jump; CMJ: countermovement jump; } 1 \mathrm{RM} \text { : one-repetition maximum; MBI: magnitude-based } \\
\text { inferences; IR1: intermittent recovery test level } 1 ; \mathrm{VO}_{2 \max } \text { : maximum rate of oxygen consumption; }{ }^{\mathrm{a}} \text { the } \\
\text { drink contained other substances such as beta-alanine and quercetin, which are not considered ergogenic } \\
\text { when ingested acutely; }\end{array}$} \\
\hline
\end{tabular}


597 Table 3. Results of the methodological quality assessment using the Physiotherapy Evidence-

598 Based Database (PEDro) scale.

\begin{tabular}{|c|c|c|c|c|c|c|c|c|c|c|c|c|}
\hline Reference & $\begin{array}{c}\text { Item } \\
1\end{array}$ & Item 2 & Item 3 & $\begin{array}{c}\text { Item } \\
4\end{array}$ & $\begin{array}{c}\text { Item } \\
5\end{array}$ & $\begin{array}{c}\text { Item } \\
6\end{array}$ & $\begin{array}{c}\text { Item } \\
7\end{array}$ & $\begin{array}{c}\text { Item } \\
8\end{array}$ & $\begin{array}{c}\text { Item } \\
9\end{array}$ & $\begin{array}{c}\text { Item } \\
10\end{array}$ & $\begin{array}{c}\text { Item } \\
11\end{array}$ & Score \\
\hline $\begin{array}{l}\text { Algrain et } \\
\text { al. (2015) }\end{array}$ & Yes & Unclear & Unclear & Yes & Yes & Yes & Yes & Yes & Yes & Yes & Yes & 8 \\
\hline $\begin{array}{l}\text { Carswell } \\
\text { et al. } \\
(2020)\end{array}$ & Yes & Yes & Unclear & Yes & Yes & Yes & Yes & Yes & Yes & Yes & Yes & 9 \\
\hline $\begin{array}{l}\text { Davenport } \\
\text { et al. } \\
(2020)\end{array}$ & Yes & Yes & Unclear & Yes & Yes & Yes & Yes & Yes & Yes & Yes & Yes & 9 \\
\hline $\begin{array}{l}\text { Giersch et } \\
\text { al. (2018) }\end{array}$ & No & Yes & Unclear & Yes & Yes & Yes & Yes & Yes & Yes & Yes & Yes & 9 \\
\hline $\begin{array}{l}\text { Grgic et } \\
\text { al. (2020a) }\end{array}$ & Yes & Yes & Unclear & Yes & Yes & Yes & Yes & Yes & Yes & Yes & Yes & 9 \\
\hline $\begin{array}{l}\text { Guest et } \\
\text { al. (2018) }\end{array}$ & Yes & Yes & Unclear & Yes & Yes & Yes & Yes & Yes & Yes & Yes & Yes & 9 \\
\hline $\begin{array}{l}\text { Klein et } \\
\text { al. (2012) }\end{array}$ & Yes & Unclear & Unclear & Yes & Yes & Yes & Yes & No & Yes & Yes & Yes & 7 \\
\hline $\begin{array}{l}\text { McGrath } \\
\text { (2015) }\end{array}$ & Yes & Yes & Unclear & Yes & Yes & Yes & Yes & Yes & Yes & Yes & No & 8 \\
\hline $\begin{array}{l}\text { Muñoz et } \\
\text { al. (2020) }\end{array}$ & Yes & Yes & Unclear & Yes & Yes & Yes & Yes & Yes & Yes & Yes & Yes & 9 \\
\hline $\begin{array}{l}\text { Pataky et } \\
\text { al. (2016) }\end{array}$ & Yes & Yes & Unclear & Yes & Yes & Yes & Yes & Yes & Yes & Yes & Yes & 9 \\
\hline $\begin{array}{l}\text { Potgieter } \\
\text { (2013) }\end{array}$ & Yes & Yes & Unclear & Yes & Yes & Yes & Yes & No & Yes & Yes & No & 7 \\
\hline $\begin{array}{l}\text { Puente et } \\
\text { al. (2018) }\end{array}$ & Yes & Yes & Unclear & Yes & Yes & Yes & Yes & Yes & Yes & Yes & Yes & 9 \\
\hline $\begin{array}{l}\text { Rahimi } \\
\text { (2018) }\end{array}$ & Yes & Yes & Unclear & Yes & Yes & Yes & Yes & Yes & Yes & Yes & Yes & 9 \\
\hline $\begin{array}{l}\text { Salinero et } \\
\text { al. (2017) }\end{array}$ & Yes & Yes & Unclear & Yes & Yes & Yes & Yes & Yes & Yes & Yes & Yes & 9 \\
\hline $\begin{array}{l}\text { Southward } \\
\text { (2016) }\end{array}$ & Yes & Yes & Unclear & Yes & Yes & Yes & Yes & Yes & Yes & Yes & Yes & 9 \\
\hline $\begin{array}{l}\text { Spineli et } \\
\text { al. }(2020)\end{array}$ & No & Yes & Unclear & Yes & Yes & Yes & Yes & Yes & Yes & Yes & Yes & 9 \\
\hline $\begin{array}{l}\text { Womack } \\
\text { et al. } \\
(2012)\end{array}$ & Yes & Yes & Unclear & Yes & Yes & Yes & Yes & Yes & Yes & Yes & Yes & 9 \\
\hline
\end{tabular}


Figure 1. Flow diagram of the search process

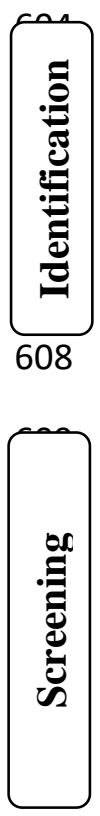

614

615

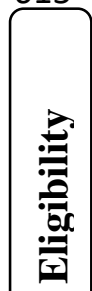

620

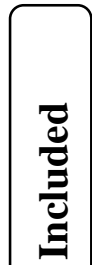

626

627

628

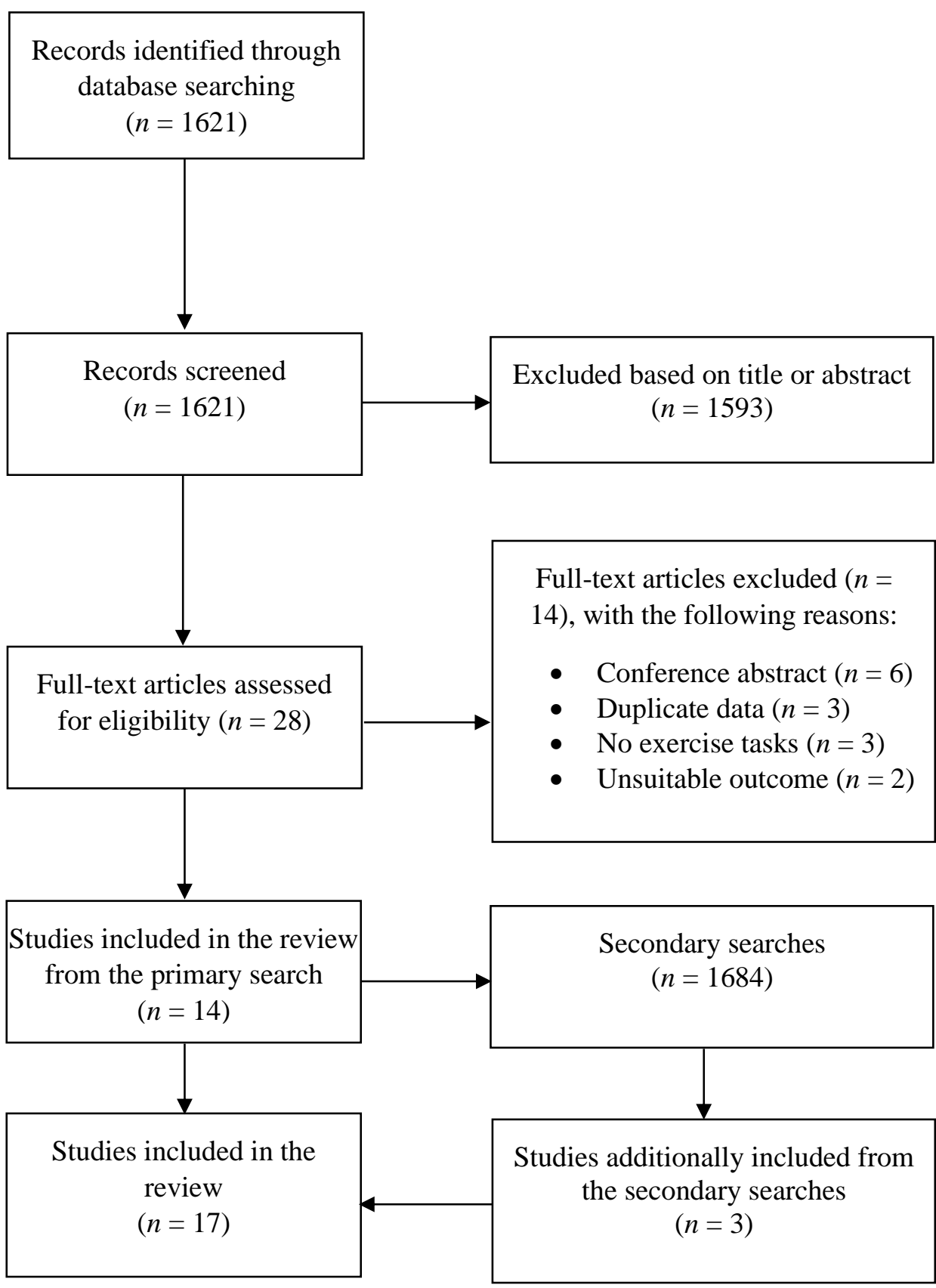

